\title{
Role of Oxidative Stress on Age and Gender
}

Sailaja M. V*1, Sharan B. Singh M 2, Ch. Rajendhra ${ }^{3}$, N. Mallikarjuna Reddy ${ }^{4}$.

${ }^{* 1}$ Assistant Professor, Dept. of Physiology, RIMS, Kadapa, Andhra Pradesh, India.

2 Professor, Dept of Physiology, Narayana Medical College, Nellore, Andhra Pradesh, India.

${ }^{3}$ Tutor. Dept. of Biochemistry, RIM S, Kadapa, Andhra Pradesh, India.

${ }^{4}$ Professor \& HOD, Dept of Physiology, Narayana Medical College, Nellore, Andhra Pradesh, India.

\section{ABSTRACT}

Background: Old age is an incurable disease which is more affected by the oxidative stress by damaging the DNA and disruptions in normal mechanisms of cellular signaling. There are dates which show possible role of oxidative stress and disturbance in antioxidant mechanisms in various disorders.

Materials and Methods: A cross-sectional study was undertaken for a period of 12 months with clinically normal 109 subjects at the Narayana General Hospital, Nellore. Were divided into 6 groups (decade a group) and target for the level of Malondialdehyde (MDA) a lipid peroxidation product and marker of oxidative stress and protein carbonyls (PCO) levels reflects the protein oxidation process. Reduced Glutathione (GSH) is a representative of antioxidant potency of glutathione system in erythrocytes, and Uric acid (UC) for the antioxidative capacity.

Result: Increased MDA, PCO, and uric acid levels. Decreased GSH levels were found. MDA and PCO significantly positively correlated. GSH significantly negatively correlated. UC was not associated with age. M DA, PCO, and GSH levels are independents of age. UC have significant gender difference. MDA and PCO were having strong negative correlation with GSH. MDA, PCO, and UC levels are significantly high in above 50 years compared to blow 50 years. GSH levels are significantly low in above 50 years compared to blow 50 years.

Conclusion: Oxidative stress (MDA \& PCO) increases with age and antioxidant activity (GSH) decreases with age. Uric acid (antioxidant) increases with age but gender difference is seen. Oxidative damage in the cell is accumulating with age and there is simultaneous decrease in the antioxidant capacity. Thus, Oxidative stress is considered as one of the causes for Aging and Age related diseases.

KEY WORDS: MDA, PCO, GSH, UC, Oxidative Stress, Antioxidative Capacity, Age.

Address for correspondence: Dr. Sailaja Muparala Venkata, Assistant Professor, Dept. of Physiology, RIMS, Kadapa, Andhra Pradesh, India. E-Mail: kvsailaja74@gmail.com

\begin{tabular}{|c|c|c|}
\hline \multicolumn{3}{|c|}{ Online Access and Article Informtaion } \\
\hline \multirow{2}{*}{$\begin{array}{c}\text { Quick Response code } \\
\text { Dol: } 10.16965 \text { ijims.2015.103 }\end{array}$} & \multicolumn{2}{|c|}{$\begin{array}{c}\text { International Journal of Integrative Medical Sciences } \\
\text { www.imedsciences.com }\end{array}$} \\
\hline & $\begin{array}{l}\text { Received: 10-02-2015 } \\
\text { Reviewed: 10-02-2015 }\end{array}$ & $\begin{array}{l}\text { Accepted: 20-02-2015 } \\
\text { Published: 28-02-2015 }\end{array}$ \\
\hline Source of Funding: Self & \multicolumn{2}{|c|}{ Conflicts of interest: None } \\
\hline
\end{tabular}

\section{INTRODUCTION}

The oxidative stress is an imbalance between increased reactive oxygen species levels and a biological system's ability to readily detoxify the reactive intermediates or to repair the resulting damage. Disturbances of normal redox state of cells can cause toxic effects through the production of peroxides and free radicals that damage all components of the cell, including proteins, lipids, DNA and disruptions in normal mechanisms of cellular signaling. Oxidative stress is thought to be involved in the develpment of cancer, Parkinson's disease, Alzheimer's disease, atherosclerosis, heart failure, myocardial infarction, fragile $X$ syndrome, Sickle Cell Disease, lichen planus, 
vitiligo, autism, infection, and chronic fatigue syndrome. The notorious disease is prevented by the antioxidants. More recent evidences suggesting low high risk groups by using antioxidants appears to reduce the risk of heart disease, and in other diseases, such as Alzheimer's. Astra Zeneca's radical scavenging nitrone drug NXY-059 shows some efficacy in the treatment of stroke [1].

Oxidative stress (as formulated in Harman's free radical theory of aging) is also thought to contribute to the aging process. While there is good evidence to support this idea in model organisms such as Drosophila melanogaster and Caenorhabditis elegans [2, 3], recent evidence from M ichael Ristow's laboratory suggests that oxidative stress may also promote life expectancy of Caenorhabditis elegans by inducing a secondary response to initially increased levels of reactive oxygen species [4]. This process was previously named mitohormesis or mitochondrial hormesis on a purely hypothetical basis [5]. The situation in mammals is even less clear $[6,7,8]$. Recent epidemiological findings support the process of mitohormesis, with a 2007 metaanalysis indicating studies with a low risk of bias (randomization, blinding, follow-up) find that some popular antioxidant supplements (Vitamin $A$, Beta Carotene, and Vitamin E) may increase mortality risk (although studies more prone to bias reported the reverse) [9].

Aging (Lucius Annaeus Senica, Roman philosopher (4 BC - AD 65): "Old age is an incurable disease". In 1952, Sir James Sterling Ross commented in his book - The National Health Service in Great Britain: an historical and descriptive study, "You do not heal old age. You protect it, you promote it, and you extend it" $[10,11]$ is a natural process. It defined as the time related deterioration of physiological functions necessary for survival and fertility. Discoveries in medical science, improved social conditions, well developed social and medical services and increase in standard of living during the past few decades have increased the life span of man. As per 2013 census the United Nations Department of Economic and Social Affairs many people in developed countries are living up to the age of 60 years and over. In India

Int J Intg M ed Sci 2015;2(2):61-69. ISSN 2394 - 4137
$8.2 \%$ of the people are over 60 years as against $19.5 \%$ in USA. From a physiological stand point, human aging is characterized by a progressive constriction of homeostatic reserve of every organ, although rate and extent of decline vary. In India, although the percentage of aged persons to total population is low in comparison to developed countries, never-theless, the absolute size of aged population is considerable. Thus number of aged persons is continually on the increase in India and worldwide. Aging population is both a medical and sociological problem. First it poses a greater demand on health services of a community and second a greater strain is placed on the younger generation to look after them. Aging is associated with many disabilities, long term illnesses and psychological problems.

When we attempt to answer a question "What changes occur in bimolecular that lead to manifestations of aging at higher orders of complexity and then increased vulnerability to all age associated pathology", the damage caused by free radicals has been focused as the most important factor. With aging the balance is shifted towards increased ROS, thus Oxidative Stress is proposed to be one of the causes of aging and age related diseases. Oxidative Stress is one of the mechanisms which induces or promotes various diseases. This study was undertaken to understand whether there are any age related changes in oxidative stress parameters in plasma and erythrocytes of healthy individuals. Normally a balance is maintained between oxidant and antioxidant systems in the body. The oxidative stress parameters selected were M alondialdehyde (MDA) and Protein carbonyls (PCO), Reduced Glutathione (GSH) and Uric acid (UC). MDA, which is major aldehyde product of lipid peroxidation, reflects damage to lipids. Determination of PCO levels reflects the protein oxidation process. GSH, an important intracellular antioxidant, is a representative of antioxidant potency of glutathione system in erythrocytes. Due to its high concentration in plasma and being an important antioxidant, Uric acid levels were measured. Thus MDA \& PCO were selected as representatives of targets of oxidative damage and GSH \& UC for the antioxidative capacity. 


\section{MATERIAL AND METHODS}

A cross-sectional study was undertaken for a period of 12 months 109 subjects were included, from January to December 2008 at the Narayana General Hospital, Nellore.

Study subjects: During the study period apparently healthy persons, who attended the hospital for routine health check-up were subjected to an oral questionnaire after obtaining an informed written consent.

Initial screening: Personal history was obtained from the participants using a structured and pretested questionnaire. General physical examination and systemic physical examination was performed to rule out any diseases or abnormalities that are likely to interfere with the study objectives. Three recordings of blood pressure were measured using a mercury sphygmomanometer (Diamond \&india) after the subject had rested comfortably in a supine position for 10 minutes. The mean of the last two readings were considered. Subjects who were normal on physical examination and who met the inclusion and exclusion criteria were selected.

Inclusion criteria: Age Between 18 -79 years, both males and females were included, Clinically normal on CVS and Respiratory examination, Blood Pressure =Systolic $<139 \mathrm{~mm}$ $\mathrm{Hg}$, Diastolic $<90 \mathrm{~mm} \mathrm{Hg}$, No History of medication, which are likely to alter oxidative stress parameters (Eg: Selenium or Vitamin C containing drugs), No History of Hypertension and No History of Diabetes M ellitus.

Exclusion criteria: Age Under 18 and above 79 years, History of any chronic disease, Individuals with any acute infections and History of any drug ingestion, which are likely to interfere with oxidative stress parameters.

Sample collection and estimation of parameters: Total $5 \mathrm{ml}$ of blood was collected; $3 \mathrm{ml}$ in plain for the measurement of $\mathrm{M}$ alondialdehyde (MDA), protein carbonyls (PCO), and uric acid, and $2 \mathrm{ml}$ in EDTA added tube for the erythrocyte glutathione (GSH) after overnight fasting from the subjects. Fasting blood glucose levels were estimated by Enzymatic Calorimetric method (GOD-PAP M ethod) to exclude diabetes.
The reagents used were of analytical grade (Himedia, Fisher-chemicals). The assays of MDA, PCO and GSH were done using Double Beam Spectro-photometer (UV-VIS-2201, Systron(s-2007). The estimation of FBS, Uric acid and total protein were done using Fully Automated Biochemical Analyser, Humastar 300 (Human.GmbH-2006). Haemoglobin was estimated using cell counter, 5 Part-Diff (Beckman-2007).

Statistical analysis: SSSPS 12.0 software (SSPS Inc., Chicago II, USA) was used for statistical analysis. Continuous variables were expressed as mean values \pm SD. Pearson' correlation coefficients were used to assess the association between the continuous variables. Differences of OXIDATIVE STRESS parameters between the groups were examined using Student's t-test and the test of ANOVA (for non- dichotomous variables). Pearson's chi-square test was used to evaluate the differences in proportions between the groups. A two tailed $p$ value $<0.05$ was considered statistically significant.

\section{RESULTS AND TABLES}

General description of the subjects: Age distribution of the study subjects ( $n=109)$, whose age ranged from 18 to 79years. M ean age of the subjects is 44.51years, Standard Error of M ean is 1.557, and Standard Deviation is 16.363.

Table 1: Age and Gender distribution of study subjects $(\mathrm{n}=109)$.

\begin{tabular}{|c|c|c|c|}
\hline \multirow{2}{*}{$\begin{array}{c}\text { Age of the subject } \\
\text { (years) }\end{array}$} & \multicolumn{2}{|c|}{ Gender, $\mathbf{n}(\%)$} & \\
\cline { 2 - 4 } & Male & Female & Total \\
\hline $\mathbf{1 8 - 2 9}$ & $9(42.9 \%)$ & $12(57.1 \%)$ & 21 \\
\hline $\mathbf{3 0 - 2 9}$ & $15(60.0 \%)$ & $10(40.0 \%)$ & 25 \\
\hline $\mathbf{4 0 - 4 9}$ & $11(68.8 \%)$ & $5(31.3 \%)$ & 16 \\
\hline $\mathbf{5 0 - 5 9}$ & $14(56.0 \%)$ & $11(44.0 \%)$ & 25 \\
\hline $\mathbf{6 0 - 6 9}$ & $8(72.7 \%)$ & $3(27.3 \%)$ & 11 \\
\hline $\mathbf{7 0 - 7 9}$ & $2(18.2 \%)$ & $9(81.8 \%)$ & 11 \\
\hline Total & $59(54.1 \%)$ & $50(45.9 \%)$ & 109 \\
\hline
\end{tabular}

$P$ Value $=0.073$ (Not significant). This table shows that the distribution of the study subjects is uniform across age and gender. 
Table 2: Distribution of Oxidative stress parameters.

\begin{tabular}{|c|c|c|c|c|}
\hline & $\begin{array}{c}\text { Malondialdehyde } \\
(\mu \mathrm{mol} / \mathrm{L})\end{array}$ & $\begin{array}{c}\text { Protein } \\
\text { Carbonyls } \\
(\mu \mathrm{mol} / \mathrm{gm} \\
\text { of protein) }\end{array}$ & $\begin{array}{c}\text { GSH } \\
(\mu \mathrm{mol} / \mathrm{gm} \\
\text { of Hb) }\end{array}$ & $\begin{array}{l}\text { Uric acid } \\
(\mu \mathrm{mol} /)\end{array}$ \\
\hline Mean & 4.34 & 1.854 & 5.948 & 326.97 \\
\hline $\begin{array}{c}\text { Standard Error } \\
\text { of Mean }\end{array}$ & 0.134 & 0.05 & 0.102 & 5.042 \\
\hline $\begin{array}{c}\text { Standard } \\
\text { Deviation }\end{array}$ & 1.404 & 0.523 & 1.063 & 52.638 \\
\hline
\end{tabular}

The table shows Mean and Standard Deviation (SD) of the oxidative stress parameters, MDA, PCO, GSH and Uric acid, of the total subjects.

Table 3: Comparison of Mean values of oxidative parameters of different age groups:

a) M alondialdehyde ( $\mu \mathrm{mol} / \mathrm{L})$ Vs Age(completed years)

\begin{tabular}{|c|c|c|c|}
\hline $\begin{array}{c}\text { Groups according to } \\
\text { age(years) }\end{array}$ & Mean & $\begin{array}{c}\text { Standard } \\
\text { Deviation }\end{array}$ & p-Value \\
\hline $\mathbf{1 8 - 2 9}$ & 2.46 & 0.69 & \\
\cline { 1 - 3 } $\mathbf{3 0 - 3 9}$ & 3.5 & 0.39 & \\
\cline { 1 - 3 } $\mathbf{4 0 - 4 9}$ & 4.47 & 0.891 & \multirow{2}{*}{$0.000 *$} \\
\cline { 1 - 3 } $\mathbf{5 0 - 5 9}$ & 5.13 & 0.478 & \\
\cline { 1 - 3 } $\mathbf{6 0 - 6 9}$ & 5.79 & 0.608 & \\
\cline { 1 - 3 } $\mathbf{7 0 - 7 9}$ & 6.4 & 0.328 & \\
\hline \multicolumn{4}{|c|}{ *significant. } \\
\end{tabular}

This table shows the mean MDA values of different age groups. From this data it is evident that MDA levels are gradually increasing with age. The $p$-value $=0.000$, which is highly significant.

b) Protein Carbonyls ( $\mu \mathrm{mol} / \mathrm{gm}$ of protein) Vs Age.

\begin{tabular}{|c|c|c|c|}
\hline $\begin{array}{l}\text { Groups according } \\
\text { to age (years) }\end{array}$ & Mean & $\begin{array}{l}\text { Standard } \\
\text { Deviation }\end{array}$ & P-Value \\
\hline $18-29$ & 1.134 & 0.188 & \multirow{6}{*}{$0.000 *$} \\
\hline $30-39$ & 1.596 & 0.188 & \\
\hline $40-49$ & 1.809 & 0.25 & \\
\hline $50-59$ & 2.121 & 0.135 & \\
\hline $60-69$ & 2.691 & 0.189 & \\
\hline $70-79$ & 1.854 & 0.215 & \\
\hline
\end{tabular}

This table shows the mean PCO values of different age groups. From this data, it is evident that PCO levels are gradually increasing with age upto age of 69years and in age group of 7079 years a little lesser mean value is noted The $p$ value $=0.000$, which is highly significant.

c) GSH ( $\mu \mathrm{mol} / \mathrm{gm}$ of $\mathrm{Hb}$ ) Vs Age.

\begin{tabular}{|c|c|c|c|}
\hline $\begin{array}{c}\text { Groups according to } \\
\text { age (years) }\end{array}$ & Mean & $\begin{array}{l}\text { Standard } \\
\text { Deviation }\end{array}$ & P-Value \\
\hline $18-29$ & 7.167 & 0.736 & \multirow{6}{*}{$0.000 *$} \\
\hline $30-39$ & 6.743 & 0.362 & \\
\hline $40-49$ & 5.957 & 0.508 & \\
\hline $50-59$ & 5.253 & 0.404 & \\
\hline $60-69$ & 5.005 & 0.423 & \\
\hline $70-79$ & 4.323 & 0.247 & \\
\hline
\end{tabular}

This table shows the mean GSH values of different age groups. From this data, it is evident that GSH levels are gradually decreasing with age. The $p$-value $=0.000$, which is highly significant.

\section{d) Uric acid ( $\mu \mathrm{mol} / \mathrm{L})$ Vs Age.}

\begin{tabular}{|c|c|c|c|}
\hline $\begin{array}{c}\text { Groups } \\
\text { according to age } \\
\text { (years) }\end{array}$ & Mean & $\begin{array}{c}\text { Standard } \\
\text { Deviation }\end{array}$ & P-Value \\
\hline $\mathbf{1 8 - 2 9}$ & 302.76 & 38.233 & \multirow{2}{*}{0.041} \\
\cline { 1 - 3 } $\mathbf{3 0 - 3 9}$ & 311.8 & 49.724 & \multirow{2}{*}{0} \\
\cline { 1 - 3 } $\mathbf{4 0 - 4 9}$ & 362.5 & 52.523 & \\
\cline { 1 - 3 } $\mathbf{5 0 - 5 9}$ & 330.92 & 48.075 & \\
\hline $\mathbf{6 0 - 6 9}$ & 343.64 & 56.701 & \\
\hline $\mathbf{7 0 - 7 9}$ & 330.36 & 63.111 & \\
\hline
\end{tabular}

This table shows the mean UC values of different age groups. From this data, it is evident that UC levels are increasing with age and it is statistically significant. But the increase is not occurring gradually with age.

\section{Correlations between Age and Oxidative stress parameters.}

a) Correlation between Age and M alondialdehyde

(MDA).

\begin{tabular}{|c|c|}
\hline Pearson Correlation & $0.911^{* *}$ \\
\hline Significance & 0 \\
\hline
\end{tabular}

** Correlation is significant at the 0.01 level.

The correlation between age and MDA showed that the Pearson's correlation coefficient was 0.911 with a $p$ value of 0.000 . This indicates age has significant effect on MDA levels with positive correlation.

Graph 1: Correlation between Age \& MDA.

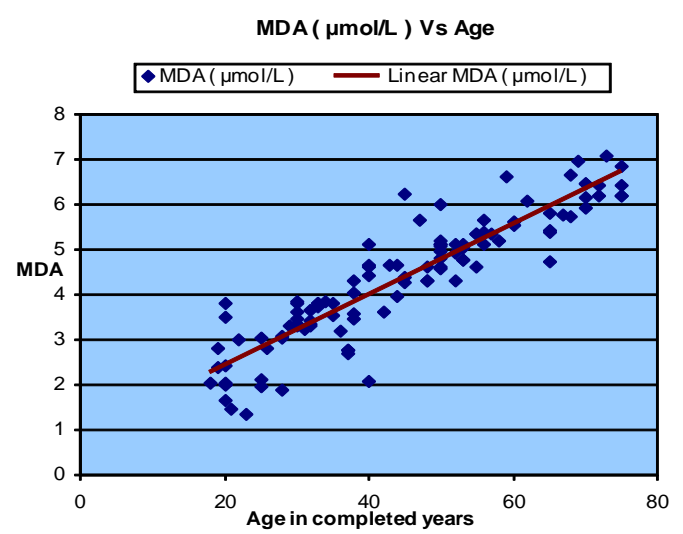

a) Correlation between Age and Protein Carbonyls (PCO).

\begin{tabular}{|c|c|}
\hline Pearson Correlation & $0.943^{* *}$ \\
\hline Significance & 0 \\
\hline
\end{tabular}

** Correlation is significant at the 0.01 level. 
The correlation between age and PCO showed that the Pearson's correlation coefficient was 0.943 with a $p$ value of 0.000 . This indicates age has significant effect on PCO levels with positive correlation.

Graph 2: Correlation between Age \& PCO.

PCO ( $\mu \mathrm{mol} / \mathrm{gm}$ of protein) Vs Age

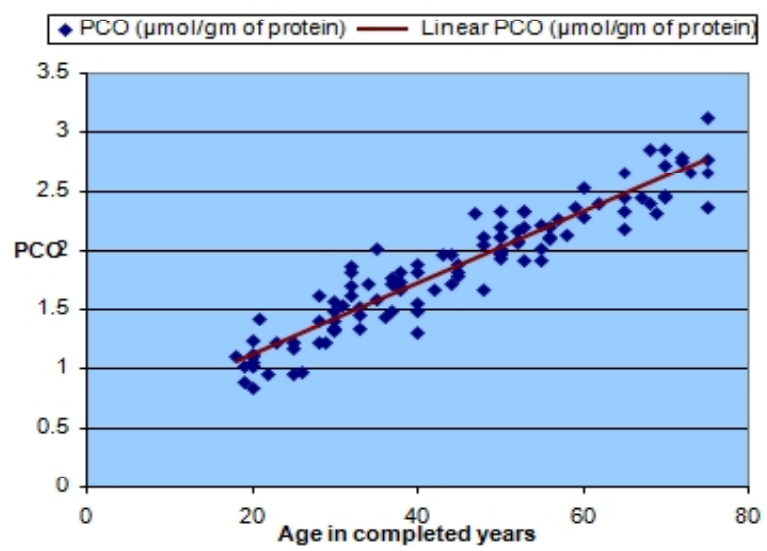

c) Correlation between Age and Reduced Glutathione (GSH)

\begin{tabular}{|c|c|}
\hline Pearson Correlation & $0.899 * *$ \\
\hline Significance & 0 \\
\hline$* *$ Correlation is significant
\end{tabular}

The correlation between age and PCO showed that the Pearson's correlation coefficient was 0.899 with a $p$ value of 0.000 . This indicates that age has significant effect on GSH levels with negative correlation.

Graph 3: Correlation between Age \& GSH. GSH ( $\mu \mathrm{mol} / \mathrm{gm}$ of $\mathrm{Hb}$ ) Vs Age

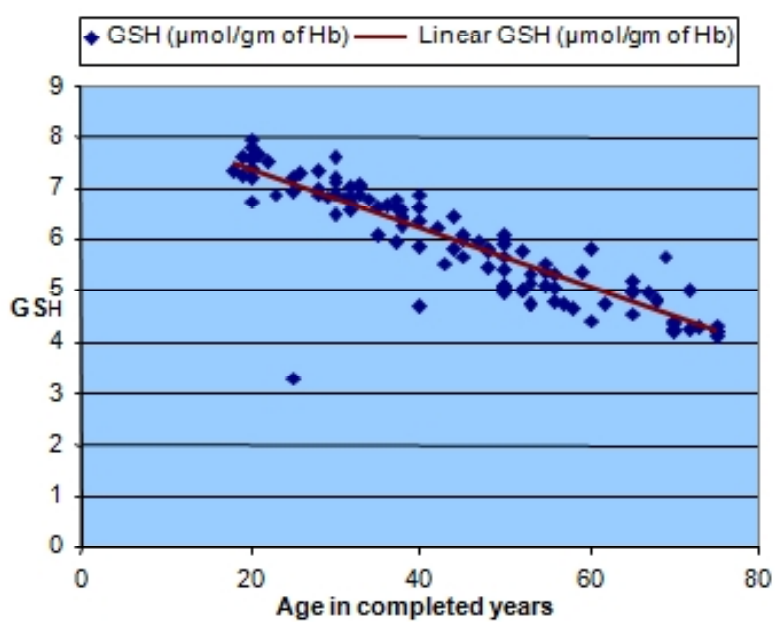

d) Correlation between Age and Uric acid

\begin{tabular}{|c|c|}
\hline Pearson Correlation & $0.196^{*}$ \\
\hline Significance & 0.041 \\
\hline
\end{tabular}

** Correlation is significant at the 0.01 level.
The correlation between age and Uric acid showed that the Pearson's correlation coefficient was 0.196 with a $p$ value of 0.041 . This indicates that there are no age associated changes in uric acid levels.

Graph 4: Correlation between Age \& UC.

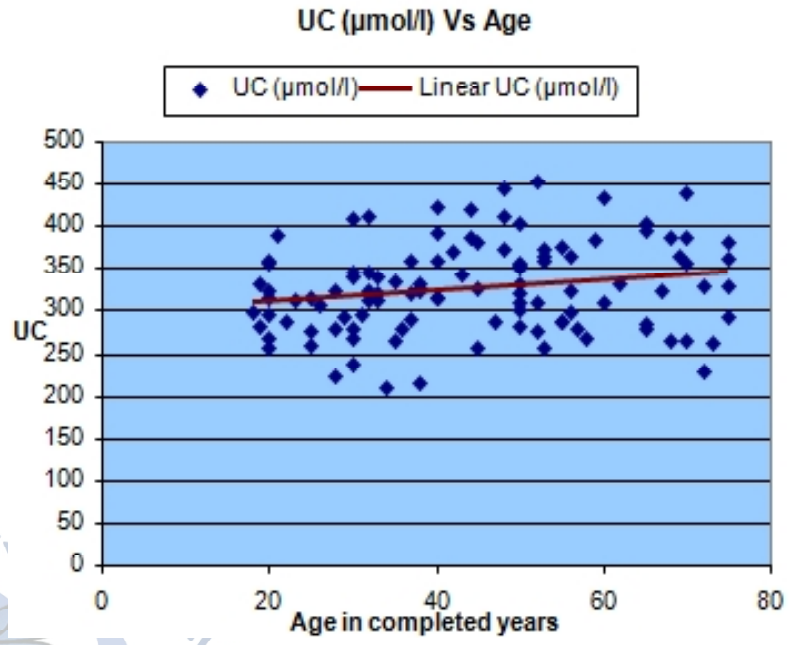

Gender wise comparison of mean values of oxidative stress parameters.

a) Malondialdehyde ( $\mu \mathrm{mol} / \mathrm{L}$ ) Vs Gender

\begin{tabular}{|c|c|c|c|c|c|}
\hline $\begin{array}{c}\text { Gender of the } \\
\text { subject }\end{array}$ & $\begin{array}{c}\text { Number } \\
\text { of subjects }\end{array}$ & Mean & $\begin{array}{c}\text { Standard } \\
\text { Deviation }\end{array}$ & $\begin{array}{c}\text { Standard Error } \\
\text { of Mean }\end{array}$ & P-Value \\
\hline Male & 59 & 4.35 & 1.249 & 0.163 & \multirow{2}{*}{0.934} \\
\hline Female & 50 & 4.33 & 1.58 & 0.223 & \\
\hline
\end{tabular}

This table shows that MDA levels are independent of gender.

b) Protein Carbonyls ( $\mu \mathrm{mol} / \mathrm{gm}$ of protein) Vs Gender

\begin{tabular}{|c|c|c|c|c|c|}
\hline $\begin{array}{c}\text { Gender of the } \\
\text { subject }\end{array}$ & $\begin{array}{c}\text { Number of } \\
\text { subjects }\end{array}$ & Mean & $\begin{array}{c}\text { Standard } \\
\text { Deviation }\end{array}$ & $\begin{array}{c}\text { Standard Error } \\
\text { of Mean }\end{array}$ & P-Value \\
\cline { 1 - 5 } Male & 59 & 1.839 & 0.496 & 0.064 & \multirow{2}{*}{0.754} \\
\hline Female & 50 & 1.871 & 0.559 & 0.079 & \\
\hline
\end{tabular}

This table shows that PCO levels are independent of gender.

c) $\mathrm{GSH}(\mu \mathrm{mol} / \mathrm{gm}$ of $\mathrm{Hb})$ Vs Gender.

\begin{tabular}{|c|c|c|c|c|c|}
\hline $\begin{array}{c}\text { Gender of the } \\
\text { subject }\end{array}$ & $\begin{array}{c}\text { Number } \\
\text { of subjects }\end{array}$ & Mean & $\begin{array}{c}\text { Standard } \\
\text { Deviation }\end{array}$ & $\begin{array}{c}\text { Standard Error of } \\
\text { Mean }\end{array}$ & P.Value \\
\hline Male & 59 & 6.033 & 0.917 & 0.119 & \multirow{2}{*}{0.37} \\
\hline Female & 50 & 5.848 & 1.215 & 0.172 & \\
\hline
\end{tabular}

This table shows that GSH levels are independent of gender. 
d) Uric acid( $\mu \mathrm{mol} / \mathrm{L})$ Vs Gender

\begin{tabular}{|c|c|c|c|c|c|}
\hline $\begin{array}{c}\text { Gender of the } \\
\text { subject }\end{array}$ & $\begin{array}{c}\text { Number of } \\
\text { subjects }\end{array}$ & Mean & $\begin{array}{c}\text { Standard } \\
\text { Deviation }\end{array}$ & $\begin{array}{c}\text { Standard Error of } \\
\text { Mean }\end{array}$ & P-Value \\
\hline Male & 59 & 337.86 & 53.686 & 6.989 & \multirow{2}{*}{$0.018^{*}$} \\
\hline Female & 50 & 314.12 & 48.825 & 6.905 & \\
\hline \multicolumn{5}{|c|}{ *significant. }
\end{tabular}

From this table it is evident that Gender differences are seen with Uric acid. Uric acid levels are found to be more in males when compared to females.

\section{Correlation between 0xidative stress para- meters with each other:}

a) Correlation between M DA \& GSH

\begin{tabular}{|c|c|}
\hline Pearson Correlation & -0.812 \\
\hline Significance & 0 \\
\hline
\end{tabular}

** Correlation is significant at the 0.01 level.

This table shows that there is strong negative correlation between MDA \& GSH and is significant at the 0.01 level.

Graph 5: Correlation between MDA $(\mu \mathrm{mol} / \mathrm{L}) \&$ $\mathrm{GSH}(\mu \mathrm{mol} / \mathrm{gm}$ of $\mathrm{Hb})$.

MDA Vs GSH

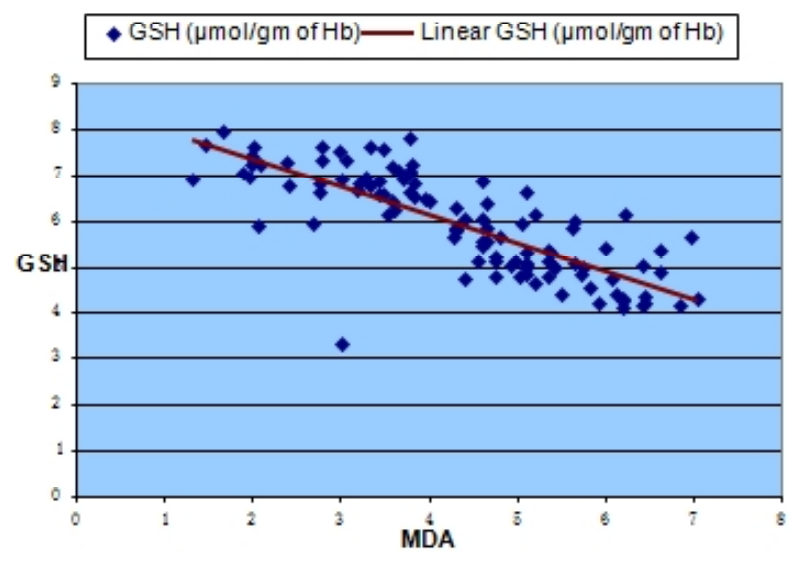

b) Correlation between PCO \& GSH

\begin{tabular}{|c|c|}
\hline Pearson Correlation & -0.859 \\
\hline Significance & 0 \\
\hline
\end{tabular}

Graph 6: Correlation between PCO ( $\mu \mathrm{mol} / \mathrm{gm}$ of protein) \& GSH ( $\mu \mathrm{mol} / \mathrm{gm}$ of $\mathrm{Hb})$

PCOVs GSH

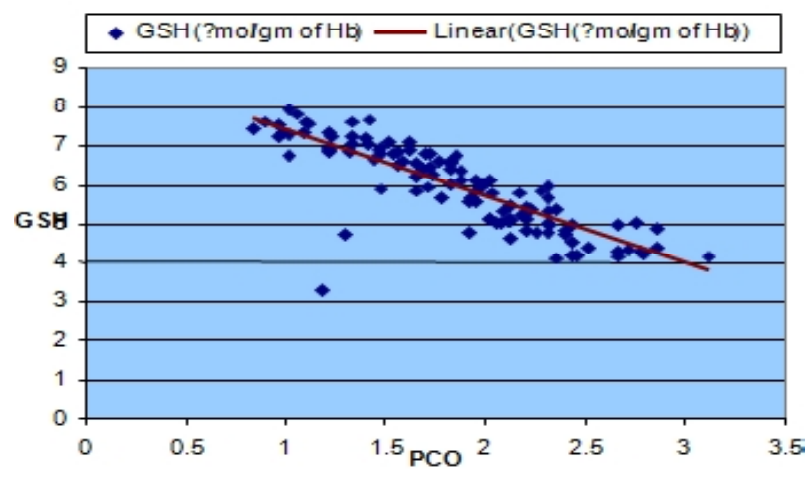

This table shows that there is strong negative correlation between PCO \& GSH and is significant at the 0.01 level.

\section{Comparison of Oxidative stress parameters in} subjects with age $<50$ years and in those with age $>50$ years:

a) Malondialdehyde (M DA) $(\mu \mathrm{mol} / \mathrm{L})$ Vs Age (<or $>$ 50 years)

\begin{tabular}{|c|c|c|}
\hline Age & $<50$ years & $>50$ years \\
\hline Number of subjects & 71 & 38 \\
\hline Mean & 3.61 & 5.71 \\
\hline Standard Deviation & 1.104 & 0.711 \\
\hline Standard Error of Mean & 0.131 & 0.115 \\
\hline \multicolumn{2}{|c|}{$0.000 *$} \\
\hline p value & *significant.
\end{tabular}

Statistically significant differences in M DA levels are seen in these two group of subjects. Significantly high levels of MDA are seen in subjects whose ages are more than 50 years.

b) Protein carbonyls (PCO) ( $\mu \mathrm{mol} / \mathrm{gm}$ of protein) Vs Age (<or $>50$ years)

\begin{tabular}{|c|c|c|}
\hline Age & $<50$ years & $>\mathbf{5 0}$ years \\
\hline Number of subjects & 71 & 38 \\
\hline Mean & 1.568 & 2.389 \\
\hline Standard Deviation & 0.375 & 0.287 \\
\hline Standard Error of Mean & 0.044 & 0.046 \\
\hline p value & \multicolumn{2}{|c|}{$0.000 *$} \\
\hline
\end{tabular}

Statistically significant differences in PCO levels are seen in these two groups of subjects. Significantly high levels of PCO are seen in subjects whose ages are more than 50 years.

c) Reduced Glutathione (GSH)( $\mu \mathrm{mol} / \mathrm{gm}$ of $\mathrm{Hb}$ ) Vs Age (< or $>50$ years).

\begin{tabular}{|c|c|c|}
\hline Age & $<\mathbf{5 0}$ years & $>\mathbf{5 0}$ years \\
\hline Number of subjects & 71 & 38 \\
\hline Mean & 6.533 & 4.856 \\
\hline Standard Deviation & 0.794 & 0.475 \\
\hline Standard Error of Mean & 0.094 & 0.077 \\
\hline p value & \multicolumn{2}{|c|}{$0.000 *$} \\
\hline \multicolumn{2}{|c}{ *significant. }
\end{tabular}

Statistically significant differences in GSH levels are seen in these two groups of subjects. Significantly low levels of GSH levels are found in subjects whose ages are more than 50 years. 
d) Uric acid (UC)( $\mu \mathrm{mol} / \mathrm{L})$ Vs Age (<or $>50$ years).

\begin{tabular}{|c|c|c|}
\hline Age & $<\mathbf{5 0}$ years & $>\mathbf{5 0}$ years \\
\hline Number of subjects & 71 & 38 \\
\hline Mean & 323.42 & 333.61 \\
\hline Standard Deviation & 50.45 & 56.593 \\
\hline Standard Error of Mean & 5.987 & 9.181 \\
\hline p value & \multicolumn{2}{|c|}{0.338} \\
\hline
\end{tabular}

Uric acid levels of subjects whose ages are less 50 years do not differ much from those of age more than 50 years.

\section{DISCUSSION}

Oxidative stress i.e. attacks of macromolecules (DNA, Proteins and Lipids) of the cell by the reactive oxygen species (ROS) is a cause of cellular damage and pathology. The generation of these ROS, which is a minor toxic byproduct of oxidative phosphorylation in mitochondria, increases with age and accumulation of the damage caused by these ROS, to macromolecules, is considered as a cause for aging and age related diseases. In order to test whether the age related change of oxidative stress parameters is taking place gradually or not, the study subjects were divided into 6 groups, each group representing one decade (except for first group which was from 18 to 29 years, as we had taken e" 18 years as adults.), and tested for differences between the groups. In our study, it was found that there were age related increases in MDA, PCO and UC levels and an age related decrease in GSH levels. The most significant differences were found between subjects whose age was less than 50years and those whose age was more than 50 years. The increase in MDA levels with age was due to oxidative damage to the polyunsaturated fatty acid in membranes of the cell, caused by the ROS, the production of which increases with age. Similarly, the increase in PCO levels with age was due to oxidative stress of proteins by ROS, i.e. increased oxidation of proteins.

A few other studies also show similar results of increase in M DA with age [12-18] and increase in PCO levels [19] with age. The above changes in MDA and PCO reflect damage to lipids and proteins caused by ROS with age. In contrast, in one study by Madlyn I. Frisard et. al. [20], an accumulation of oxidative damage with age could not be shown as measured by Urinary isoprostanes, PCO \& DNA fragmentation. In their study no significant differences in the PCO levels with age were found. They stated that accumulation of oxidative stress is greater in postmitotic tissues (such as skeletal muscle and brain) than in other cell types with faster turnover rates (such as blood), which might partially account for the fact that there were no differences detected between age groups with regard to protein carbonyls in serum. Age groups and number of subjects taken in their study were 20-34 ( $n=47), 60-74$ ( $n=49)$, and $\geq 90$ years ( $n$ =74). Whereas the sample size and age groups of our study ( $n=109$, aged from 18-79 years divided into decades) differ considerably from their study.

In our study a decrease in antioxidant capacity, as noted by decrease in intraerythrocytic GSH levels, confirms the earlier results which show significant negative correlation of GSH with age $[13,21-22,18]$. Thus glutathione redox system is impaired with age. This may be the result of age-related decrease in the activity of glutamate cysteine ligase, a rate-limiting enzyme in de novo synthesis of GSH, leading to a decrease in antioxidant potency of the body [22]. The increase in MDA \& PCO levels with age and decrease in GSH with age coincide with the results of studies by Lizette Gil et al [22]. However a decrease in GSH levels with age as seen in our study is contradictory to the study by Kai Tanabe et. al.[14], where they stated that age has little influence on antioxidant capacity and oxidative stress among people with advancing age. In another study by MendozaNunez Victor et. al.[19], no age related changes in oxidative stress markers were seen in subjects with age less than 60 years. They measured the levels of MDA and that of GSH system (GSSG \& GSH). They also found an increase in oxidative stress in subjects with age more than 60 years.

In our study it was noted that there is an age related increase in Uric acid levels. This is in contradiction to the results in the study by Lizette Gil [22], where they found Uric acid levels are independent of age and they stated that UC levels are largely influenced by nutrition and, 
therefore, oxidative stress might have minor influence. The increase in UC levels with age in our study may be due to smaller sample size and emphasizes the need for further studies on uric acid levels. The increases in uric acid levels with age coincide with the results of study by Mark A. Reynolds et. al. [16] in one of the genotypic strains of inbred mice. Form my study we also looked for gender associated differences in these oxidative stress parameters. Except for Uric acid, there were no differences in the levels of M DA, GSH and PCO between genders, which coincide with the reports of $M$ ine Erden-nal et. el. [20] and others [16, 23]. In our study UA levels are higher in males when compared to females. This is in accordance with the previous study by Lizette Gil [22]. This signifies the fact that Uric acid is influenced mostly by nutritional and metabolic factors rather than by oxidative stress. In our study, we also sought for the correlation of oxidative stress parameters with each other. We found that there was a strong negative correlation between MDA \& GSH and similarly between $P C O \& G S H$. This suggests that oxidative damage accumulates with age as noted by increase in M DA\& PCO levels and may be due to a concomitant impairment of antioxidant system as noted by decrease in the levels of GSH. These findings are in confirmation with other studies [12, 21, and 17]. Thus in our study we found that there was a gradual increase of MDA \& PCO levels with age and a gradual decrease in GSH levels with age. From this, it is evident that the balance between prooxidants and antioxidants shifts towards oxidants with age.

\section{CONCLUSION}

Finally, we concluded from my study based on the evidence levels of parameters the Oxidative stress (M DA \& PCO) increases with age and antioxidant activity (GSH) decreases with age. Uric acid (antioxidant) increases with age but gender difference is seen for uric acid (more in males when compared to females). It is also found that there is interdependence between the parameters. A strong negative correlation between MDA and GSH and similarly a strong negative correlation between PCO and GSH are observed. From the present study, it can be stated that Oxidative damage in the cell is accumulating with age and there is simultaneous decrease in the antioxidant capacity as evidenced by a decrease in GSH levels. Thus, Oxidative stress is considered as one of the causes for Aging and Age related diseases.

\section{REFERENCES}

[1]. Oxidative stress Wikipedia. http://en.wikipedia.org/ wiki/Oxidative stress accessed on dec 2008

[2]. Larsen PL. Aging and resistance to oxidative damage in Caenorhabditis elegans. Proc Natl Acad Sci U S A. 1993 Oct 1;90(19):8905-9.

[3]. Helfand SL, Rogina B. Genetics of aging in the fruit fly, Drosophila melanogaster". Annu Rev Genet. 2003;37:329-48.

[4]. Schulz TJ, Zarse K, Voigt A, Urban N, Birringer $M$, Ristow $M$. Glucose restriction extends Caenorhabditis elegans life span by inducing mitochondrial respiration and increasing oxidative stress. Cell Metab. 2007 Oct;6(4):280-93.

[5]. Tapia PC. Sublethal mitochondrial stress with an attendant stoichiometric augmentation of reactive oxygen species may precipitate many of the beneficial alterations in cellular physiology produced by caloric restriction, intermittent fasting, exercise and dietary phytonutrients: "Mitohormesis" for health and vitality. Med Hypotheses. 2006;66(4):832-43. Epub 2005 Oct 18.

[6]. Sohal RS, M ockett RJ, Orr WC. M echanisms of aging: an appraisal of the oxidative stress hypothesis". Free Radic Biol Med. 2002 Sep 1;33(5):575-86.

[7]. Sohal RS. Role of oxidative stress and protein oxidation in the aging process". Free Radic Biol Med. 2002 Jul 1;33(1):37-44.

[8]. Rattan SI Theories of biological aging: genes, proteins, and free radicals". Free Radic Res. 2006 Dec;40(12):1230-8.

[9]. Bjelakovic G, Nikolova D, Gluud LL, Simonetti RG, Gluud C. Mortality in randomized trials of antioxidant supplements for primary and secondary prevention: systematic review and metaanalysis. JAMA. 2007 Feb 28;297(8):842-57.

[10]. Jhilam Rudra De. Management of old age- a critical problem in Indian perspective across culture \& time. Available at www.esocialsciences.com.

[11]. John C. Bailar, Jr. Moses Gomberg. Biographical Memoirs of the National Academy of Science 1970:41:141.

[12]. Weir, J.H, Roy. Soc. HIth Jr; 1967:87:144-149.

[13].Ozbay B, Dülger H.Lipid peroxidation and antioxidant enzymesin Turkish population: relation to age, gender, exercise, and smoking. Tohoku J Exp Med. 2002 Jun;197(2):119-24. 
[14]. Kai Tanabe, Kazumi Masuda et al. Relationships between Age, Daily Physical Activity, Antioxidant Capacity and Oxidative Stress among M iddle-aged and Elderly People. International Journal of Sport and Health Science Vol.4, 515-527, 2006

[15]. Makbule Aydýn, Elif Ozkok, Salih Cengiz. Changes in oxidative stress in Wistar albino rats during senescence. Adv M ol Med 2007; 3(4): 171-175.

[16].Mark A. Reynolds, Donald K. Ingram and Richard G. Cutler. Serum uric acid: Correlation with behavioral, metabolic, age, and lifespan parameters among inbred mice. AGE, Springer Netherlands, 1984:7: (4): 93-9.

[17]. Matsubara LS, M achado PE. Age-related changes of glutathione content, glutathione reductase and glutathione peroxidase activity of human erythrocytes. Braz J M ed Biol Res. 1991;24(5):44954.

[18]. Rizvi SI, M aurya PK. Markers of oxidative stress in erythrocytes during aging in humans. Ann N Y Acad Sci. 2007 Apr;1100:373-82.

[19].M endoza-Núñez VM, Ruiz-Ramos M, SánchezRodríguez M A, Retana-Ugalde R, M uñoz-SánchezJL. Aging-related oxidative stress in healthy humans. Tohoku J Exp Med. 2007 Nov;213(3):261-8.
[20]. M adlyn I. Frisard, Amanda Broussard et al. Protein Damage M easured by Protein Carbonyls RO Aging, Resting M etabolic Rate, and Oxidative Damage: Results From the Louisiana Healthy Aging Study. J Gerontol A Biol Sci Med Sci. 2007 Jul; 62(7): 752759.

[21].Lang CA, Naryshkin S, Schneider DL, Mills $\mathrm{BJ}$, Lindeman RD. Low blood glutathione levels in healthy aging adults. J Lab Clin Med. 1992 Nov; 120(5):720-5.

[22]. Gil L, Siems W, M azurek B, Gross], Schroeder P, Voss $\mathrm{P}$, Grune T. Age-associated analysis of oxidative stress parameters in human plasma and erythrocytes. Free Radic Res. 2006 M ay;40(5):495505.

[23]. M ine Erden-nal, Emine Sunal, Güngör Kanbak. Agerelated changes in the glutathione redox system. Cell Biochem Funct. $2002 \mathrm{M}$ ar;20(1):61-6.

\section{How to cite this article:}

Sailaja M. V, Sharan B. Singh M, Ch. Rajendhra, N. M allikarjuna Reddy. Role of Oxidative Stress on Age and Gender. Int J Intg M ed Sci 2015;2(2):61-69. DOI:10.16965/ijims.2015.103 